\title{
Study of the psychological preparation on the dental care of children with special needs
}

Estudo da eficácia do preparo psicológico no atendimento de crianças portadoras de necessidades especiais
João Carlos da Rocha

Institute of Science and Technology, UNESP - Univ Estadual Paulista, São José dos Campos (SP), School of Dentistry, Department of Social and Pediatric Dentistry

\section{Abstract}

The psychology in Dentistry is a great challenge for the clinicians during the care of their patients. The conditioning of a patient to achieve a behavior meeting the professional's needs for developing a procedure within the quality standards is necessary. When this conditioning focuses on the child patients the challenge is even greater because the child will use all ways to make difficult the action of the clinician due to fear or discomfort. The ability of the dentist to condition the patient will be directly proportional to the training and theoretical knowledge acquired. Considering the Patients with Special Needs (PSN), this training should be differentiated because there is the physical, cognitive, and the previous dental/medical history in addition to the psychological and emotional difficulties. The aim of this study was to evaluate the profile of the patient to be conditioned satisfactorily and which conditioning techniques would be more efficient to ambulatory dental care of PSN. Thirty patients, both genders, aged from 20 months to 11 years-old who were enrolled at the ambulatory treatment of NEAPE were observed. It was concluded that when there is the cognitive development of the individual, they are able to be conditioned for the ambulatory care; the use of auxiliary methods is important in the conditioning for the ambulatory care of the individuals; the syndromic patients had the best results for the conditioning aiming to the ambulatory care; there was a significant improvement in the behavior of individuals between the first and last appointments.

\section{KeYWORDS}

Dentistry; Pediatric dentistry; Patients with special needs; Psychology.

\section{Resumo}

A psicologia em odontologia é um grande desafio para os profissionais no atendimento clínico de seus pacientes. Condicionar um paciente para que este tenha um comportamento condizente com as necessidades do profissional para o desenvolvimento de um procedimento dentro dos padrões de qualidade torna-se necessário. Quando este condicionamento tem como foco o paciente infantil este desafio é extremamente exarcebado, pois a criança usará de todos os meios para que dificulte a ação do profissional, ou por medo ou desconforto. O destreza do profissional em condicionar o paciente será diretamente proporcional ao treinamento e conhecimento teórico por ele adquirido. Com os Pacientes Portadores de Necessidades Especiais (PNE) este treinamento deverá ser diferenciado pois além das dificuldades psicológicas e emocionais temos as limitações físicas, cognitivas e com sua história médica/ odontológica pregressa. A proposta deste trabalho foi avaliar que perfil de paciente pode ser condicionado de modo satisfatório e quais técnicas de condicionamento são mais eficazes para o tratamento odontológico em ambulatório de PNE. Foram observados 30 pacientes, de ambos os sexos, com idade entre 20 meses a 11 anos, que freqüentavam o ambulatório do NEAPE. Concluímos que: quando existe um desenvolvimento cognitivo do individuo, os indivíduos são passiveis de serem condicionados para o atendimento ambulatorial; o uso de métodos auxiliares é importante no condicionamento para o atendimento ambulatorial dos indivíduos; os pacientes sindrômicos foram os de melhor resultados no condicionamento para atendimento ambulatorial; existiu melhoria significante no comportamento dos indivíduos entre a primeira e ultima sessão de atendimento.

\section{UNITERMOS}

Odontologia; Odontopediatria; Pacientes com necessidades especiais; Psicologia. 


\section{INTRODUCTION}

In Dentistry, the Psychology is a rich field of studies and researches because there are different sources and trends in both fields aiming to understand better the human behavior facing different daily situations. Since Sigmund Freud (so-called the father of the psychoanalysis) with his many theories, passing through Alfred Adler with his power theory, and Carl Gustav Yung with all his mysticism, among many others who studied the human behavior and its development, Jean Piaget and Vygotsky could also be cited because they were concerned in understanding how the human beings learn and store the information and how they use and codify this learning in daily basis. It was searched to understand how the human mind functions, how the human beings reacts and how better we could employ all this potential to improve the quality of life of the individuals [1-4].

The child experiences situations starting during the mother's pregnancy or even from conception which reflected in the reactions to stimulus according to that which was learned in these occasions In the period of the first childhood - crucial for a good development in a psychologically healthy adult who passes through the following Freud's phases: oral, sadist and anal; as well as the Piaget's phase of learning -, the child develops capacities and behavior reactions which will influence on the rest of their lives [5-10].

The patient with special needs (PSN) presents a different behavior profile and answers differently in relation to the behavior expected from a patient without special needs $[11,12]$.

Patients with or without special needs, at matched ages, may have responses previously expected. Therefore, many authors divide them by relating the reactions with the chronological age [1,5,13-16].

When one thinks about the psychological preparation in Dentistry, the intention is to search an expected behavior that enables the intervention always respecting the chronological and mental age, and mainly the level of comprehension of the patient. Patients who show the minimum of comprehension are capable of being psychologically conditioned to undergo to dental procedures without great demands. On the other hand, patients with a very restricted level of comprehension will difficultly have understanding and satisfactory dialogue to undergo to even a smaller procedure $[2,5,11,17]$.

Our clinical expertise has shown that most of the patients enrolled at the Center for Study and Dental Care of Patients with Special Needs (NEAPE) can be conditioned for an ambulatory care without the need of referrals to dental treatment under general anesthesia or sedation. However, these are occasional observations without a scientific study, mensuration, analysis and comparison with other authors and we are unable to affirm which method for procedure would work [18,19].

Even during adverse conditions, where physical restraint is necessary at first, methods of psychological conditioning can be employed to reach a treatment without restraint [20-24].

Considering this aforementioned discussion the aim of this study was to evaluate the patient's profile which would enable the satisfactory conditioning as well as which would be the most efficient techniques of psychological conditioning for the ambulatory dental care of patients with special needs.

\section{Material and Method}

This study was submitted and approved by the Ethical Committee in Research of the School of Dentistry of São José dos Campos - UNESP, under protocol number 114/2003-PH/CEP.

The sample was composed by 30 patients, both genders, with special needs, aged from 20 months to 11 years-old and treated in the ambulatory care of the Center for Study and Dental Care of Patients with Special Needs (NEAPE), of the Department of Social Dentistry and Child Clinic of the School of Dentistry of São José dos Campos - SP - UNESP.

To qualify the individuals, clinical forms which were routinely filled in for the treatment of these patients were used and analyzed through the modified Frankl scale for behaviors [25], indicating only the behavior of the patient in: positive $(+)$ or negative(-) according to Oliveri \& Alves (2001)[21].

The children were divided into 4 age groups:

Group I - 0 to 2 years and 11 months;

Group II -3 years to 5 years and 11 months;

Group III -6 years to 8 years and 11 months;

Group IV - above 9 years.

Exclusion criteria comprised patients with severe mental deficiency, severe physical involvement and uncontrolled behavioral disturbs. Thus, the sample was composed by patients capable of being conditioned for the dental ambulatory care.

Concerning to the procedures employed, the classification was per appointments[21]:

$1^{\text {st }}$ appointment - psychological conditioning (adaptation appointment)(AA), clinical examination(CE), techniques of oral hygiene $(\mathrm{TH})$ and prophylaxis $(\mathrm{P})$; 
$2^{\text {nd }}$ appointment - psychological conditioning, radiographs $(\mathrm{RX})$, adequacy of oral environment (AOE);

$3^{\text {rd }}$ appointment - psychological conditioning, restorations without absolute isolation (R), application of topical fluoride (F);

$4^{\text {th }}$ appointment - procedures demanding anesthesia (A);

$5^{\text {th }}$ appointment-procedures with absolute isolation (AI).

During these five appointments, the collection of data was performed. When at least one of the aforementioned procedures was executed, the appointment was considered as valid. In some occasions, other procedures were transferred to the nest appointment. The fifth appointment comprising the use of the absolute isolation was reconsidered and it was not included as an exclusion criterion because in most of the PSN individuals the use of absolute isolation is contraindicated.

Up to 3 appointments were accepted for the psychological conditioning of the child and none case required more than three conditioning appointments [22]

At the ending of each appointment, the procedures were recorded both by the examiner and assistant with either a positive sign $(+)$ for a satisfactory behavior or negative sign (-) for an unsatisfactory behavior.

The psychological conditioning of the patients comprised the following methods: tell-show-do (TSD), mimicking, desensibilization, positive reward, distraction and voice control (VC) $[1,12,14,22]$.

\section{Results}

After the obtaining and tabulation of the data collected during the five appointments of clinical treatment, the results found are seen in the figures and tables below:
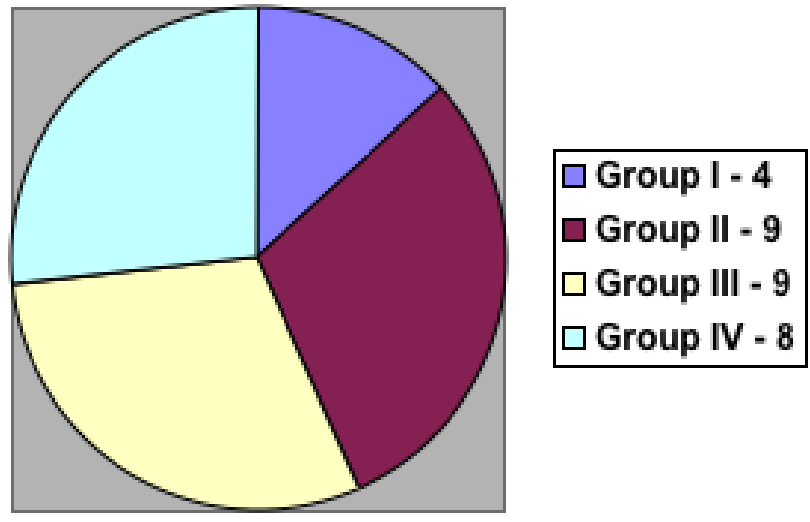

Figure 1 - Number of children per age groups.

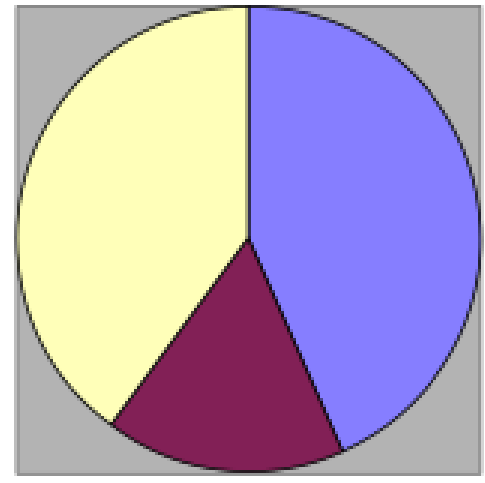

$\square$ Syndromic - 13

- CP -5

$\square$ Others - 12

Figure 2 - Number of children per type of pathology.

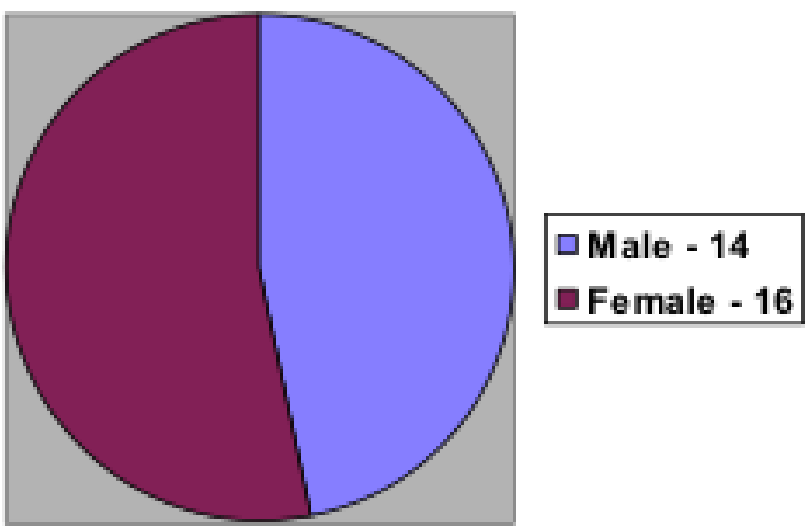

Figure 3 - Division of the sample according to gender.

Table 1 - Results of McNemar test, level of SIGNIFICANCE OF $\mathbf{5} \%$

\begin{tabular}{|c|c|c|c|c|c|c|c|c|c|c|c|c|c|c|}
\hline \multirow{3}{*}{$\begin{array}{l}\text { Category } \\
\text { Behavior }\end{array}$} & \multicolumn{2}{|c|}{ Scores } & \multicolumn{12}{|c|}{ Variation* } \\
\hline & \multirow[t]{2}{*}{+} & \multirow[t]{2}{*}{ - } & \multicolumn{3}{|c|}{$\begin{array}{l}\text { Initial } \\
\text { vs. } 2^{\text {nd }}\end{array}$} & \multicolumn{3}{|c|}{$\begin{array}{l}\text { Initial } \\
\text { vs. } 3^{\text {rd }}\end{array}$} & \multicolumn{3}{|c|}{$\begin{array}{l}\text { Initial } \\
\text { vs. } 4^{\text {th }}\end{array}$} & \multicolumn{3}{|c|}{$\begin{array}{l}\text { Initial } \\
\text { vs. } 5^{\text {th }}\end{array}$} \\
\hline & & & + & - & 0 & + & - & 0 & + & - & 0 & + & - & 0 \\
\hline Initial & 13 & 17 & 7 & 0 & 23 & 12 & 7 & 11 & 15 & 1 & 14 & 12 & 0 & 18 \\
\hline Second & 20 & 10 & & & & & & & & & & & & \\
\hline Third & 13 & 17 & & & & & & & & & & & & \\
\hline Fourth & 13 & 17 & & & & & & & & & & & & \\
\hline Fifth & 13 & 17 & & & & & & & & & & & & \\
\hline
\end{tabular}

\section{Discussion}

According to the data obtained in this study, one can observe how much the behavior of the human being is diversified and how difficult is the search for a behavior pattern for dental care.

It was difficult to standardize the procedures because each individual from the sample demanded 
a different procedure resulting in some changing in the initial proposal of each appointment (Figure 2). Notwithstanding, it was not possible to follow the specifications of each appointment at the expense of the needs of each individual. The ethics must be ahead of any other parameter aiming to the respect of the human being, mainly when dealing with PSN, who requires a differentiated view of the professional because of their more demanding needs.

The syndromic patients showed the best results, especially those exhibiting Down Syndrome because of the easiest communication and comprehension. The worst performance was presented by younger patients because of the difficult of communication and comprehension due to their poor cognitive development as well as by patients in whom the pathology affects the comprehension and attention. (Figures 1 and 2)

Generally, it was verified that PSN who show any type of comprehension are capable to be conditioned for the ambulatory dental care.

The use of alternative ways helps in the conditioning of the individuals, so that the reward because of a good behavior is of great value for the motivation of the patients. The voice control is efficient when well applied. The affection, understanding, acceptance, first contact, respect to the difficulties and limitations are elements which when well observed make easy the interaction and acceptance of the required procedures.

Concerning to the male and female genders, difference was not noted regarding to the behavior among the individuals of the sample (Figure 3). Only the approach should be differentiated respecting the individuality and the communication way.

It was difficult to compare the results of this present study with those finding in literature because there are no studies on PSN and all the parameters are established in patients without these necessities. This makes any comparison impracticable. The expertise in Pediatric Dentistry may cause the impression that the treatment of PSN would be more demanding, but this is more related to the limitations than to the cognitive development of the individuals.

Through the McNemar test, by comparing each appointment, with level of significance of $5 \%$, it was observed that there was an improvement in the behavior of the individuals.

According Table 1, from the first to the second appointment, thirteen individuals who showed a positive behavior kept this same behavior during the next appointment; ten patients who started with a negative behavior kept it during the next appointment; seven who showed a negative behavior, behaved well during the next appointment; and no patients who behaved positively in the first appointment exhibited a negative behavior in the next appointment. These results showed that the well-conditioned patient was able to improve or maintain the behavior over the treatment because there was no case of worsening in the behavior while seven cases improved the pattern.

From the second to the third appointment (Table 1) it was observed that twelve individuals kept the positive behavior; four maintained the negative behavior; eight improved the behavior and six worsened the behavior. By analyzing these results, it was noted that the more complex the procedures the worst the behavior because of the discomfort of the individual who tend to refuse the procedures.

From the third to the fourth appointment (Table 1) it was observed that seventeen individuals kept the positive behavior; two individuals kept the negative behavior; one patient had a worse behavior and ten improved their behavior. As the conditioning was applied in all appointments, we expected that an improvement would occur despite of the most complex procedures with greater discomfort. When the patient starts to trust in the dentist, the insecurity, the subjective fear and the objective fear are well faced by the individual. The individual may express its difficulties and the professional can help to surpass these problems.

From the fourth to the fifth appointment (Table 1), we observed that twenty-four individuals who had satisfactory behavior kept it; two patients showed an unsatisfactory behavior and maintained it; three individuals improved their behavior and one showed a worse behavior. It was noted a gradual and constant improvement in the behavior of the individuals which denotes the efficacy of the psychological conditioning. Although some individuals changed their behavior during the appointments, the result showed during the last appointment was very satisfactory.

When the first and last appointment was compared (Table 1), we observed that all thirteen patients who had had a positive behavior kept it; of the seventeen individual who had had a negative behavior at the first appointment, five kept it and twelve improved the behavior. By analyzing these results, we reached an objective analysis with statistic data demonstrating the efficacy of a good psychological conditioning of the individuals leading to the maintenance and improvement of the behavior for an efficient treatment with quality both for the patient and the professional. 
When the dentists fail to observe the real need of the psychological conditioning in any profile of patients, especially those with special needs, the comprehensive treatment is forgotten, focusing only in the specialty. The patients to be submitted to dental care cannot be seen as a mouth, stomach or only a sick person; they must be understood as a human being. Since the conception, passing through the newborn, and during all the life of any individual, the human being should be respected and considered. This patient cannot be submitted to the following disrespects: "the waiting room is full", "I don't have time for other talking", "this is nothing", "he/she does not deserve a treatment because he/she will die anyway", "it is not worth wasting time because he/she is a burden to society", and "newborns do not fell pain".

The need of a different care for the PSN leads to the demanding of the inter-disciplinarily, searching for a better life condition, to decrease the suffering and also to the need for the use of drugs to reach the ambulatory care of PSN. A good psychological conditioning seems to be the safest way for a better dental care of PSN.

\section{Conclusion}

According to the methodology used and results obtained by this present study, it can be concluded that:

1. When there is a cognitive development of the individuals, which enables a good comprehension of the world around them, the individuals are capable of being conditioned for the ambulatory care;

2. The use of auxiliary methods is important in the conditioning for the ambulatory care of the individuals;

3. The syndromic patients showed the best results in the conditioning for the ambulatory care.

4. There was a significant improvement in the behavior of the individuals between the first and last appointment of the treatment.

\section{References}

1. Albuquerque CM, Gouvêa CVD, Moraes RCM, Barros RN, Couto CF. Principais técnicas de controle de comportamento em Odontopediatria. Arq Odont. 2010;45(2):110-5.

2. Allen KD, Stokes TF. Use of escape and reward in the management of young children during dental treatment. J Appl Behav Anal. 1987 Winter;20(4):381-90.

3. Arnrup K, Berggren U, Broberg AG, Lundin S, Hakeberg M. Attitudes to dental care among parents of uncooperative vs. Cooperative child dental patients. Eur J Oral Sci. 2002 Apr;110(2):75-82.

4. Jung CG. Psicologia do inconsciente. 7.ed. Rio de Janeiro: Vozes; 1987.

5. Aragone PN. Aspectos psicológicos na clínica odontopediátrica aplicados à relação criança-famíliadentista. J Bras Odontop Odontol Bebe. 1998;2(5):23-7.

6. Faraco Júnior IM, Percinoto ACBDC. A influência do acompanhante sobre o comportamento da criança durante o tratamento odontopediátrico: os AA Avaliam a importância da presença de um acompanhante na sala clínica durante o tratamento odontopediátrico. RGO. 1994;42(6):323-5.

7. Fontes LBC, Alves RA, Santos VIM, Grinfeld S, Montandon EM. Psicologia: transferência e contratransferência na clínica odontopediátrica. J Bras Odont Bebe. 1999;2(7):179-81.

8. Gonçalves SRM, Segretti OMA, Borges AMC. Medo em odontopediatria; por que e do que as crianças têm medo no tratamento odontológico: técnicas de condicionamento através do toque sutil. Rev Paul Odont 1993;15(6):35-40.

9. Johnson, RB. Maternal Anxiety and Child Behavior. ASDC J Dent Child. 1969 Mar-Apr;36(2):87-92.

10. Salvari LFC, Dias CMSB. Os problemas de aprendizagem e o papel da família: uma análise a partir da clínica. Estud Psicol. 2006; 23(3):251-9.

11. Fonseca ALA, Azzalis LA, Fonseca FLA, Botazzo C. Análise qualitativa das percepções de cirurgiões-dentistas envolvidos nos atendimentos de pacientes com necessidades especiais de serviços públicos municipais. Rev Bras Crescimento Desenvolv Hum. 2010;20(2):208-16.

12. Nathan JE. Behavioral management strategies for young pediatric dental patients with disabilities. ASDC J Dent Child. 2001 Mar-Apr;68(2):89-101.

13. Aartman IH, van Everdingen T, Hoogstraten J, Schuurs AH. Self-report measurements of dental anxiety and fear in children: a critical assessment. ASDC J Dent Child. 1998 Jul-Aug;65(4):252-8, 229-30.

14. Ferreira JMS, Aragão AKR, Colares V. Técnicas de controle do comportamento do paciente infantil: revisão de literatura. Pesq Bras Odontoped Clin Integr. 2009;9(2):247-51.

15. Klatchoian DA. Psicologia odontopediátrica. São Paulo: Santos; 2002.

16. Nobrega MSG. Importância dos conhecimentos psicológicos em odontopediatria. Odont. Mod. 1995;223(3):10-8.

17. Poulton R. Good teeth, bad teeth and fear of the dentist. Behav Res Ther. 1997 Apr;35(4):327-34.

18. Aubuchon RW. Sedation liabilities in pedodontics. Pediatr Dent. 1982;4:171-80.

19. Badra A. Hipnose em odontologia e odontologia psicossomática: nova dimensão na odontologia atual. São Paulo: Andrei; 1987.

20. Carr KR, Wilson S, Nimer S, Thornton JB. Behavior management techniques among pediatric dentists practicing in the southeastern United States. Pediatr Dent. 1999 SepOct;21(6):347-53. 
21. Oliveri JLS, Alves UM. Controle do comportamento: a chave do sucesso em odontopediatria. Pesq. Bras. Odontop. Clin. Integr. 2001;1(3):3-7.

22. Tavares MJ, Modesto A, Tostes Amaral M, Rédua PCB, Vianna R. Avaliação dos métodos de controle do comportamento infantil utilizados por dentistas enfatizando mão sobre a boca e restrição física. Rev Assoc Bras Odontol. 2000;8(5):296-301.

23. Tharash W, Mizes S. The origin and prevention of dental fears. Clin Prev Dent. 1984 Sep-Oct;6(5):28-32.

24. Townend E, Dimigen G, Fung D. A clinical study of child dental anxiety. Behav Res Ther. 2000 Jan;38(1):31-46.

25. Frankl SN, Shiere FR, Fogels HR. Should the parent remain with child in the dental operatory? ASDC J Dent Assoc. 1962;29:150-63.
Received: 2012-11-14

Accepted: 2013-04-01

\section{Corresponding Author}

João Carlos da Rocha Institute of Science and Technology, UNESP - Univ Estadual Paulista, São José dos Campos (SP), School of Dentistry, Department of Social and Pediatric Dentistry Av. Eng. Francisco José Longo, 777 - São Dimas - São José dos Campos - São Paulo - Brasil 